\title{
JENIS-JENIS BAMBU (BAMBUSOIDEAE) DI PULAU BENGKALIS, PROVINSI RIAU, INDONESIA
}

\author{
Indra Rijaya \& Fitmawati \\ Jurusan Biologi, Fakultas Matematika dan Ilmu Pengetahuan Alam, Universitas Riau, Kampus Binawidya \\ Jl. HR. Soebrantas Km 12.5 Pekanbaru 28293, Riau, Indonesia \\ Corresponding author: indrarijayaindra@gmail.com
}

Indra Rijaya \& Fitmawati. 2019. Bamboo Species (Bambusoideae) in Bengkalis Island, Riau Province, Indonesia. Floribunda 6(2): 41-52. - Bengkalis Island is one of the islands in the eastern part of Sumatra dominated by peaty substrate with bamboo species that viewed to have ecological, hydrological and economic value. There is little information about the bamboo diversity in this island. The purpose of this study was to inventory and identify bamboo based on their morphological characters. Sampling was done by using exploration methods. This study found four native genera (Bambusa, Dendrocalamus, Gigantochloa, Schizostacyum) and one introduced genera (Thyrsostachys). Nine species i.e (B. glaucophylla, B. heterostachya, B. multiplex, B. vulgaris, D. asper, G. hasskarliana, S. brachycladum, S. latifolium and T. siamensis, and one variety $B$. vulgaris var. striata, is observed.

Keywords: Bamboo, Bengkalis Island, identification, inventory.

Indra Rijaya \& Fitmawati. 2019. Jenis-jenis Bambu (Bambusoideae) di Pulau Bengkalis, Provinsi Riau, Indonesia. Floribunda 6(2): 41-52. - Pulau Bengkalis merupakan salah satu pulau di sisi timur Sumatra yang didominasi lahan gambut dengan tumbuhan bambu yang dipercaya memiliki peran ekologis, hidrologis dan ekonomis. Informasi mengenai jenis-jenis bambu yang ada di Pulau Bengkalis sangatlah sedikit. Tujuan penelitian ini adalah untuk melakukan inventarisasi dan identifikasi jenis-jenis bambu berdasarkan karakter morfologi. Metode penelitian yang digunakan adalah metode survey eksploratif. Berdasarkan penelitian ini diperoleh empat marga asli bambu yakni Bambusa, Dendrocalamus, Gigantochloa, Schizostacyum dan satu marga introduksi (Thyrsostachys) Sembilan jenis yaitu (B. glaucophylla, B. heterostachya, B. multiplex, B. vulgaris, D. asper, G. hasskarliana, S. brachycladum, S. latifolium dan T. siamensis, dan satu varietas yaitu B. vulgaris var. striata dikemukakan.

Kata kunci: Bambu, identifikasi, inventarisasi, Pulau Bengkalis.

Bambu tergolong kedalam suku Poaceae, anak suku Bambusoideae (Wong 2004; Widjaja 2001a). Bambu adalah tumbuhan serbaguna yang mudah diperoleh dan banyak dimanfaatkan oleh masyarakat untuk berbagai kebutuhan, seperti alat rumah tangga, juga bermanfaat secara, ekologi, sosial dan budaya (Widjaja \& Karsono 2005). Secara ekologi bambu mampu menjaga keseimbangan lingkungan karena mempunyai sistem perakaran yang dapat mencegah terjadinya erosi (Wong 2004), menjaga sistem hidrologis karena memiliki kemampuan sebagai pengikat air, sehingga dapat digunakan sebagai tumbuhan pengkonservasi tanah dan air (Dahlan 1994 dalam Widjaja et al. 1994; Sukawi 2010; Widnyana 2012).

Jumlah bambu di dunia terdiri atas 1.439 jenis dengan 116 marga (Bamboo Phylogeny Group 2012). Indonesia memiliki kurang lebih $11.5 \%$ dari jenis bambu di dunia dengan 161 jenis bambu yang terdiri atas 12 marga asli Indonesia dan 10 marga introduksi. Saat ini, Pulau Sumatra adalah sentral keanekaragaman hayati bambu Indonesia dengan jumlah jenis endemik yang terbanyak dibandingkan dengan pulau lain yang ada di Indonesia yakni dengan 80 jenis dengan 32 jenis merupakan jenis endemik (Widjaja 2014). Jumlah ini diperkirakan masih dapat bertambah bila ekplorasi dilakukan lebih intensif, terutama di daerah pulau-pulau kecil di Indonesia (Widjaja 2001b). Salah satu pulau di sisi timur Pulau Sumatra yang masih kurang informasinya tentang jenis-jenis bambu adalah Pulau Bengkalis.

Pulau ini terdiri dari satu kabupaten yakni Kabupaten Bengkalis dengan luas lahan gambut sebesar 856.017,67 ha atau 21,2\% dari luas lahan gambut di Provinsi Riau. Dominasi lahan gambut menyebabkan kualitas air di area ini kurang baik (Wahyunto \& Heryanto 2005; Wahyunto et al. 2005). Salah satu keunikan bambu adalah mampu menjaga sistem hidrologis sebagai pengikat tanah dan air, serta akarnya dapat menyaring air menjadi lebih bersih. Dengan demikian bambu dapat digu- 
nakan untuk menjaga ketersediaan air dalam tanah dengan kualitas yang lebih baik (Widnyana 2012; Soekartawi 1995). Selain itu, bambu memiliki kemampuan untuk meningkatkan kualitas lahan dan kesuburan tanah secara fisik, kimia, dan biologi (Hartutiningsih \& Siregar 1996). Dengan keunikan dan kemampuan bambu ini maka informasi tentang jenis-jenis bambu yang tumbuh di Pulau Bengkalis menjadi penting dan dapat membantu dalam upaya mengkonservasi air.

\section{BAHAN DAN METODE}

Penelitian dilakukan dengan pengambilan sampel jenis-jenis bambu dari beberapa lokasi di Pulau Bengkalis. Bahan yang digunakan adalah alkohol 70\%, sampel bambu, kertas koran, kertas label, selotip dan lem. Lokasi penelitian dilakukan diseluruh Pulau Bengkalis yang terdiri dari Kecamatan Bengkalis dan Kecamatan Bantan, terletak di $1^{\circ} 28^{\prime} 29.17^{\prime \prime}$ LU dan $120^{\circ} 17^{\prime} 40.71 "$ BT. Peta lokasi penelitian disajikan dalam gambar 1 .

Pengambilan spesimen menggunakan metode deskriptif eksplorasi yakni dengan menemukan tegakan bambu, baik tumbuh liar maupun budidaya, mendeskripsikannya dan membuat kunci identifikasi (Rugayah et al. 2004). Pembuatan spesimen herbarium mengikuti prosedur standar oleh Bean (2013) dan Wondafrash (2008) dengan pengepresan dan pengeringan serta pencatatan kelengkapan data herbarium. Sampel yang diperoleh dalam kondisi segar didokumentasikan, kemudian dikeringkan dengan menggunakan oven di Herbarium Bogoriense, Puslit Biologi, Cibinong, Jawa Barat. Pengamatan morfologi untuk identifikasi seperti tipe akar rimpang; rebung; percabangan; pelepah buluh; daun dan bunga jika tersedia mengacu pada kriteria yang digunakan Dransfield \& Widjaja (1995), Widjaja (1997), Widjaja (2001a), Widjaja (2001b) dan Widjaja et al. (2005).

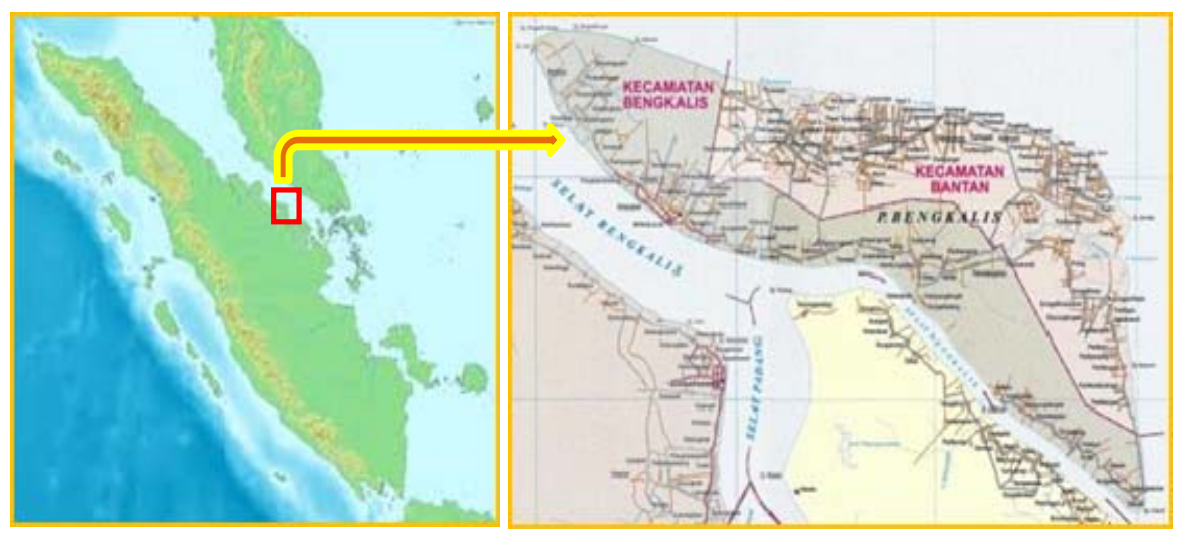

Gambar 1. Lokasi penelitian di Pulau Bengkalis Provinsi Riau (sumber: situs pemerintah Kab. Bengkalis 2012).

\section{HASIL DAN PEMBAHASAN}

\section{Keanekaragaman Bambu}

Berdasarkan hasil penelitian yang telah dilakukan di Pulau Bengkalis diperoleh bambu yang dapat tumbuh baik dan beradaptasi dengan tanah gambut terdiri dari empat marga asli yakni Bambusa, Dendrocalamus, Gigantochloa, Schizosta- chyum dan satu marga introduksi yakni Thyrsostachys. Sembilan jenis dan satu varietas telah teridentifikasi yakni B. glaucophylla, B. heterostachya, B. multiplex, B. vulgaris dan B. vulgaris var. striata, D. asper, G. hasskarliana, S. brachycladum, S. latifolium, dan jenis introduksi T. siamensis.

\section{Kunci identifikasi jenis-jenis bambu di Pulau Bengkalis}

1. a. Percabangan sama besar pada buku-buku bagian tengah buluh ke ujung, dinding batang tipis.

2. Schizostachyum

2. a. Warna pelepah rebung kuning kecokelatan, buku-buku dilingkari cincin putih, buluh tua berwarna hijau tua mengkilap, panjang ruas 30-40 cm, permukaan pelepah buluh berbulu kemerahan hingga cokelat muda, kuping pelepah buluh membulat kecil, memiliki bulu kejur, daun pelepah buluh dengan pangkal melebar, tegak Shizostachyum brachycladum 
b. Warna pelepah rebung hijau muda, buku-buku gundul/polos, buluh tua berwarna hijau tua tidak mengkilap, panjang ruas $65-70 \mathrm{~cm}$, permukaan pelepah buluh berbulu cokelat hingga hitam, kuping pelepah buluh membulat, dengan bulu kejur panjang, daun pelepah buluh dengan pangkal agak menyempit, waktu muda tegak kemudian terkeluk balik Schizostachyum latifolium

1. b. Percabangan dengan satu cabang lebih besar dibandingkan cabang yang lain pada buku-buku bagian bawah atau kadang hanya terdapat pada bagian tengah buluh, dinding batang tebal ... 3

3. a. Warna pelepah rebung hijau keunguan, miang pelepah rebung berwarna putih, buluh tegak sangat padat, buluh berwarna hijau keabu-abuan, ketebalan buluh $>15 \mathrm{~mm}$ terkadang hampir padat, permukaan abaksial pelepah buluh berbulu putih, daun menggaris.......Thyrsostachys siamensis

b. Warna pelepah rebung hijau kecokelatan, hijau kecokelatan dan atau bergaris kuning, kuning kecokelatan, hijau kekuningan, hijau dengan garis kuning, buluh berbiku-biku hingga tegak, agak padat, buluh berwarna hijau, kuning dengan garis hijau, hijau dengan garis kuning, hijau pucat, ketebalan buluh 5-15 mm, permukaan abaksial pelepah buluh tertutup bulu cokelat, cokelat kemerahan hingga hitam, jarang yang putih, daun melanset 4

4. a. Warna pelepah rebung hijau tua, hijau kecokelatan, hijau kekuningan, hijau dengan garis kuning, buluh berbiku-biku, ruas pendek pada buluh tengah, pelepah buluh tertutup bulu hitam (kecuali B. multiplex yang gundul), daun pelepah buluh tegak pada buluh tengah.

5. Bambusa

b. Warna pelepah rebung cokelat kehitaman, hijau kekuningan, buluh tegak, ruas panjang pada buluh tengah, pelepah buluh tertutup bulu hitam dan cokelat kemerahan, daun pelepah buluh terkeluk balik pada buluh tengah 9

5. a. Pelepah rebung hijau dengan garis kuning yang tertutup bulu hitam, pelepah buluh tidak mudah luruh atau terlambat gugur, kuping pelepah buluh membulat agak mencuat keluar, buluh tua hijau dengan garis kuning Bambusa heterostachya

b. Pelepah rebung hijau kekuningan ditutupi bulu hitam, hijau kekuningan gundul, hijau ditutupi miang cokelat tua, hijau dengan 3-4 garis kuning ditutupi miang cokelat tua, pelepah buluh mudah luruh, kuping pelepah buluh membundar bercuping keluar, gundul; buluh tua hijau kusam, buluh hijau tua mengkilap agak berlilin putih, buluh hijau tua mengkilap, buluh tua kuning mengkilap dengan garis hijau.....

6. a. Pelepah rebung tidak ditutupi miang (gundul), tidak memiliki kuping pelepah rebung, buluh berdiameter 1-1.5 cm, permukaan abaksial pelepah buluh tidak berbulu (gundul), kuping pelepah buluh tidak tampak tanpa bulu kejur, warna pelepah buluh putih kecokelatan Bambusa multiplex

b. Pelepah rebung ditutupi miang, memiliki kuping pelepah rebung, buluh berdiameter $2-13 \mathrm{~cm}$, permukaan abaksial pelepah buluh berbulu, berbulu cokelat hingga hitam, memiliki kuping pelepah buluh membundar melengkung keluar dengan bulu kejur, warna pelepah buluh berwarna cokelat muda

7. a. Pelepah rebung ditutupi miang hitam, tidak memiliki akar udara (polos), permukaan abaksial pelepah buluh berbulu hitam, daun pelepah buluh dengan pangkal menyempit, daun hijau dengan garis putih, kecil, menggaris Bambusa glaucophylla

b. Pelepah rebung ditutupi miang cokelat tua, memiliki akar udara pada bagian pangkal buluh pada 2-3 ruas pertama, permukaan abaksial pelepah buluh cokelat hingga hitam, daun pelepah buluh dengan pangkal melebar, daun tanpa garis, melanset 8

8. a. Warna pelepah rebung hijau kecokelatan, buluh hijau tua mengkilap

Bambusa vulgaris

b. Warna pelepah rebung hijau dengan 3-4 garis kuning, buluh kuning mengkilap dengan garis hijau Bambusa vulgaris var. striata

9. a. Warna pelepah rebung cokelat kehitaman ditutupi miang cokelat seperti beludru, kuping pelepah rebung membundar, diameter buluh $14-18 \mathrm{~cm}$, memiliki buku-buku akar udara dari pangkal hingga tengah keatas, pelepah buluh mudah luruh, kuping pelepah buluh membundar, daun pelepah buluh terkeluk balik Dendrocalamus asper

b. Warna pelepah rebung hijau kekuningan tertutup bulu hitam lebat, kuping pelepah rebung 
menggaris, diameter buluh 6-10 cm, memiliki buku-buku akar udara hanya di pangkal dan tengah, keatas tidak terdapat akar udara, pelepah buluh tidak mudah luruh, kuping pelepah buluh menggaris/bingkai, daun pelepah buluh menyadak hingga terkeluk balik Gigantochloa hasskarliana

\section{Deskripsi Jenis Bambu}

Berikut deskripsi tumbuhan bambu yang meliputi deskripsi, gambar morfologi dan distribusinya. Dari deskripsi tersebut akan tergambarkan perbedaan ragam bambu di Pulau Bengkalis.

\section{Bambusa glaucophylla Widjaja}

\section{Sinonim:-}

Nama umum/lokal: Bambu hias/bambu pagar/ bambu putih

Deskripsi:

Rebung ramping panjang seperti menyegitiga dengan kuncup hijau kekuningan, warna pelepah rebung hijau kekuningan ditutupi bulu hitam tidak merata; bentuk kuping membundar; posisi daun pelepah buluh tegak (Gambar 2a). Buluh muda licin kadang dengan beberapa bulu hitam tersebar, buku-buku polos (gundul), buluh tua berwarna hijau kusam, tinggi hingga $5 \mathrm{~m}$, ruas panjangnya $20-25 \mathrm{~cm}$ dengan diameter $2-3.2 \mathrm{~cm}$, ketebalan dinding buluh 2-5 mm (Gambar 2b). Pelepah buluh cokelat muda dengan permukaan abaksial ditutupi bulu hitam, mudah luruh, panjang pelepah buluh 5-7 cm, lebar pelepah buluh 2-3 cm; kuping pelepah buluh membundar bercuping melengkung keluar dengan tinggi 1-2 mm dengan bulu kejur 1-2 mm; ligula rata dengan tinggi 1-2 $\mathrm{mm}$, tepinya gundul atau agak berbulu; daun pelepah buluh tegak, menyegitiga dengan pangkal sempit, panjang daun pelepah buluh $1.9-2.3 \mathrm{~cm}$, lebar 2-2.7 cm (Gambar 2c). Percabangan muncul diseluruh buku-buku pada ruas 1-4 dengan jarak 10-25 cm, percabangan 5-6 cabang dengan satu cabang dominan dan cabang lain lebih kecil (Gambar 2d). Daun panjang 19-24 cm, lebar 1.5$2.4 \mathrm{~cm}$, berwarna hijau garis putih, permukaan atas dan bawah tidak terdapat bulu (gundul), warna tangkai daun hijau muda; permukaan pelepah daun tidak berbulu; kuping pelepah daun membundar, tinggi $1 \mathrm{~mm}$, gundul; ligula menggerigi, tinggi 1 mm; gundul (Gambar 2e).

Persebaran: Tidak diketahui secara pasti dari mana asalnya, tetapi ditanam hampir di seluruh Indonesia termasuk Pulau Sumatra, Jawa, Nusa Tenggara, dan sebagainya.

Lokasi ditemukan: Desa Kembung Luar, Kec. Bantan, Kab. Bengkalis $\left(01^{\circ} 24^{\prime} 42,7^{\prime \prime}\right.$ \& $102^{\circ} 27$ ' 41,2"). Indra Rijaya 09.

Habitat: Jenis bambu ini ditemukan pada daerah dengan kondisi terbuka dan memiliki kondisi tanah yang sedikit lembab. Dapat ditemukan pada perkarangan rumah dan kebun kota.

Pemanfaatan: Tanaman hias.
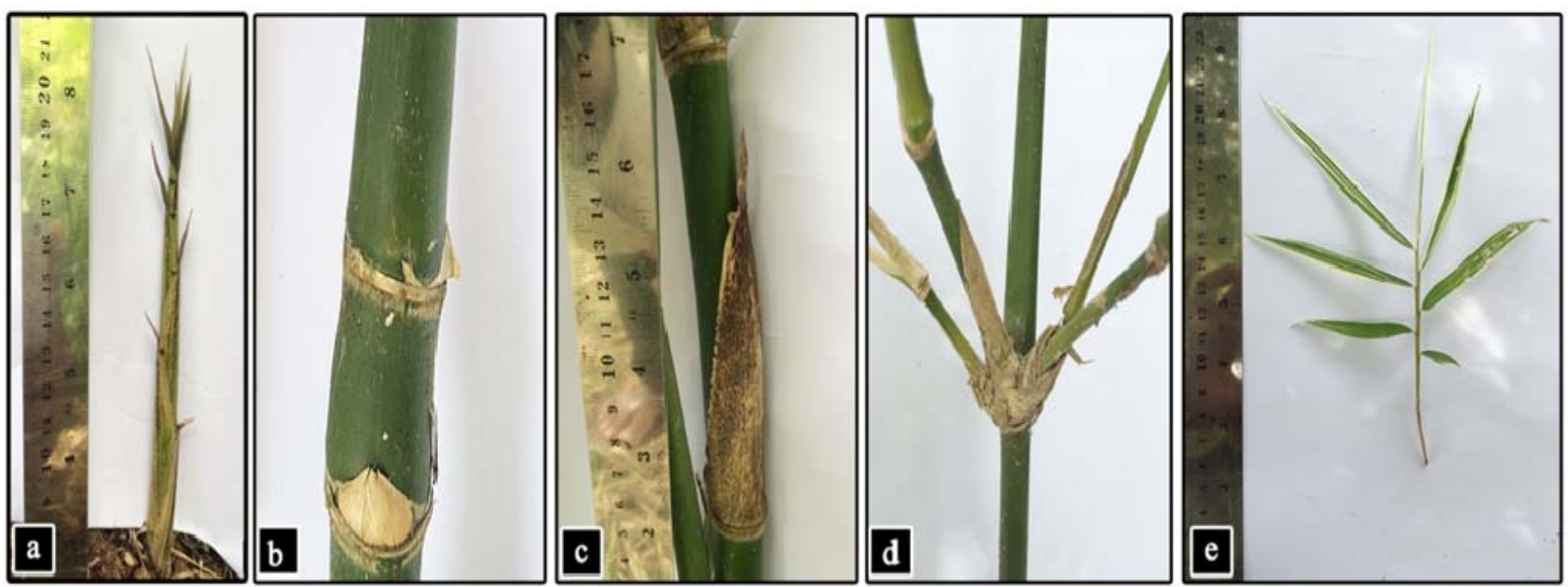

Gambar 2. B. glaucophylla a. rebung; b. buku-buku; c. pelepah buluh; d. percabangan; e. daun.

Bambusa heterostachya (Munro) Holttum Sinonim: Gigantochloa heterostachya Munro (1868), Gigantochloa latispiculata Gamble (1896), Bambusal atispiculata Gamble (1946) (Widjaja 2001b; Dransfield \& Widjaja 1995).

Nama umum/lokal: Bambu galah

Deskripsi:

Rebung bentuk ramping menyegitiga; pelepah re- 
bung hijau dengan garis-garis kuning yang tertutup bulu hitam; kuping pelepah rebung menggaris; daun pelepah rebung tegak (Gambar 3a). Buluh tegak, buku-buku licin (polos), buluh muda hijau muda tertutup lilin putih, buluh tua berwarna hijau tua bergaris kuning, tingginya mencapai $18-23 \mathrm{~m}$, diameter 6-10 cm, ketebalan dinding 6-9 $\mathrm{mm}$, ruas panjangnya 37-42 cm (Gambar 3b). Pelepah buluh tidak mudah luruh, permukaan adaksial gundul, cokelat muda tertutup bulu cokelat hingga hitam pada permukaan abaksial, panjang 10-14 cm, lebar $11-15 \mathrm{~cm}$; kuping pelepah buluh membulat agak mencuat keluar, tinggi $7-8 \mathrm{~mm}$, bulu kejur dengan panjang $8-9 \mathrm{~mm}$; ligula menggerigi dengan panjang 2-3 mm, bulu kejur mencapai 4-6 $\mathrm{mm}$; daun pelepah buluh tegak, menyegitiga dengan pangkal menyempit, panjang 5-6 cm, lebar 4 $-4.5 \mathrm{~cm}$ (Gambar 3c). Percabangan terdiri 3-10 cabang setiap ruas dengan satu cabang lateral lebih besar daripada cabang lain, cabang tumbuh terletak jauh dari permukaan tanah atau berkisar 1-1.5 m dari permukaan tanah (Gambar 3d). Daun 32-37 $\mathrm{cm} \times 3.9-4.2 \mathrm{~cm}$, permukaan atas berbulu halus, permukaan bawah gundul, warna tangkai daun hijau muda; permukaan daun tidak berbulu, kuping membulat, tinggi 1-2 mm, bulu kejur mencapai 2$3 \mathrm{~mm}$; ligula menggerigi, panjang $1 \mathrm{~mm}$ dengan bulu kejur mencapai 2-3 mm (Gambar 3e).

Persebaran: Jenis bambu ini ditanam dari biji yang diambil dari perkebunan kelapa sawit di Sumatra Utara. Awalnya berasal dari Semenanjung Malaysia (Widjaja 2001a).

Lokasi ditemukan: Desa Mentayan, Kec. Bengkalis, Kab. Bengkalis $\left(01^{\circ} 32^{\prime} 06.3^{\prime \prime} \& 102^{\circ}\right.$ 16'41.9") Indra Rijaya 05.

Habitat: Jenis ini ditemukan pada daerah lembab dan daerah tertutup, seperti di daerah perkebunan karet dan sawit.

Pemanfaatan: Galah, tiang antena dan kerajinan tangan.
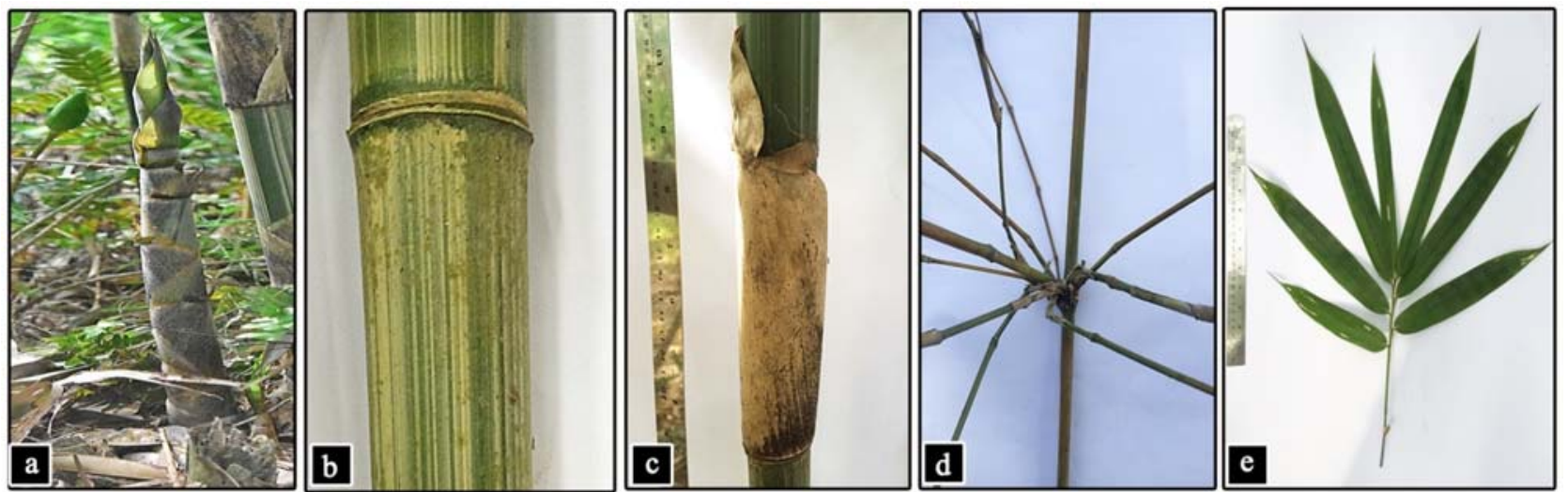

Gambar 3. B. heterostachya a. rebung; b. buku-buku; c. pelepah buluh; d. percabangan; e. daun.

Bambusa multiplex (Lour.) Raeusch. ex Schult.

Sinonim: Arundo multiplex Lour. (1790), Bambusa nana Roxb. (1832), Bambusa glaucescens (Willd.) Sieb. Ex Munro (1868) (Dransfield \& Widjaja 1995).

Nama umum/lokal: Bambu pancing.

\section{Deskripsi:}

Rebung ramping seperti jarum dengan kuncup hijau pucat, pelepah rebung hijau kekuningan, gundul; tidak memiliki kuping pelepah rebung (polos); daun pelepah rebung tegak (Gambar 4a). Buluh berbiku-biku, buku-buku polos; buluh tua hijau tua mengkilap, agak berlilin putih; tingginya mencapai 6-9 $\mathrm{m}$, diameter $1-$ $1.5 \mathrm{~cm}$, ketebalan dinding $2-4 \mathrm{~mm}$, ruas pan- jangnya 20-35 cm (Gambar 4b). Pelepah buluh mudah luruh, putih kecokelatan, permukaan abaksial tanpa bulu (gundul), dengan panjang 13-18 cm, lebar 5-7 cm; kuping pelepah buluh tidak tampak, gundul; ligula menggerigi dan tidak teratur, tinggi $1.5 \mathrm{~mm}$, gundul; daun pelepah buluh tegak dan hijau pucat, menyegitiga dengan dasar melebar, panjang daun pelepah buluh 7-9 $\mathrm{cm}$, lebar 1-2 cm (Gambar 4c). Percabangan terdiri atas 7-9 cabang yang besarnya hampir sama tetapi sering satu cabang lebih besar daripada cabang lainnya, terletak pada buku-buku di dekat tanah dengan tinggi dari permukaan tanah 25-39 cm (Gambar 4d). Daun 14-17 cm x 1.5-2 cm, permukaan atas dan bawah tidak berbulu (gundul), warna tangkai daun hijau keku- 
ningan; kuping hampir tidak tampak atau seperti bingkai (menggaris), tinggi $1-2 \mathrm{~mm}$, bulu kejur pendek; ligula tidak tampak, gundul. Perbungaan tidak ditemukan (Gambar 4e).

Persebaran: Banyak ditemukan di kota dan desa-desa di Indonesia seperti Pulau Sumatra, Jawa, Kalimantan dan sebagainya.
Kec. Bantan, Kab. Bengkalis (01 $32^{\prime} 29.3^{\prime \prime}$ \& $\left.102^{\circ} 16^{\prime} 28.1^{\prime \prime}\right)$. Indra Rijaya 08.

Habitat: bambu ini ditemukan pada daerah kering dan lembab, pada umumnya ditemukan pada pekarangan rumah dan di pinggir rawa.

Pemanfaatan: Alat pancing, tanaman pagar.
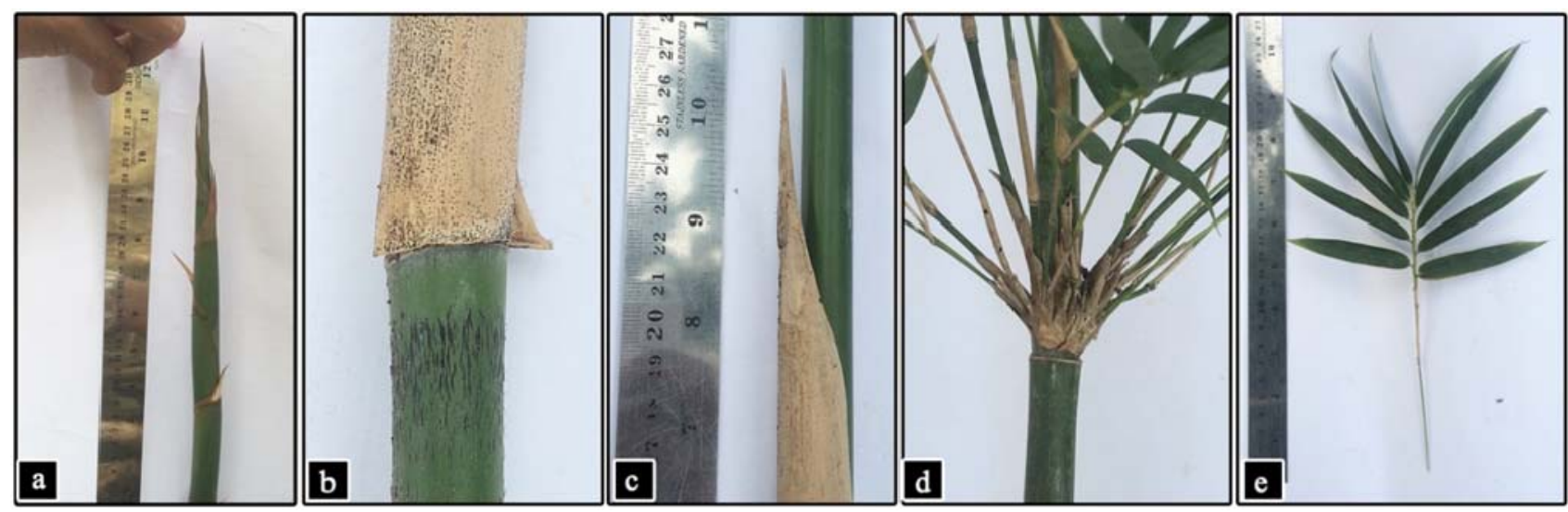

Gambar 4. B. multiplex a. rebung; b. buku-buku; c. pelepah buluh; d. percabangan; e. daun.

Bambusa vulgaris Schard. ex Wendl.

Sinonim: Bambusa thouarsii Kunth (1822)., Bambusa surinamensis Ruprecht (1839)., Leleba vulgaris (Schard. Ex Wendl.) Nakai (1933) (Dransfield \& Widjaja 1995).

Nama umum/lokal: Bambu ampel, bambu karbit, bambu pengerai.

\section{Deskripsi:}

Rebung ramping menyegitiga; pelepah rebung hijau dengan miang berwarna cokelat tua; kuping pelepah rebung membundar; daun pelepah rebung tegak (Gambar 5a). Buluh dengan buku-buku akar udara hanya di bagian pangkal dan bagian tengah keatas tidak terdapat akar udara, tegak agak berbiku-biku, buluh tua hijau tua mengkilap, tingginya $8-15 \mathrm{~m}$, diameter $8-13 \mathrm{~cm}$, ketebalan dinding 10-15 mm, ruas panjangnya $20-40 \mathrm{~cm}$ (Gambar 5b). Pelepah buluh mudah luruh, cokelat muda dengan permukaan abaksial tertutup bulu hitam hingga cokelat tua, dengan panjang 25-28 $\mathrm{cm}$, lebar 29-32 cm; kuping pelepah buluh membundar bercuping keluar, tinggi $1-1.5 \mathrm{~cm}$, panjang bulu kejur 7-10 $\mathrm{mm}$; ligula menggerigi, tinggi $2-3$ $\mathrm{mm}$ dengan bulu kejur pendek 1-2 mm; daun pelepah buluh tegak dengan pangkal menyegitiga melebar, dengan panjang $12-14 \mathrm{~cm} \times 10-12 \mathrm{~cm}$ (Gambar 5c). Percabangan setiap ruas terdiri 2-5 cabang dengan satu cabang lebih besar dari pada cabang yang lainnya, tumbuh $1.5-1.8 \mathrm{~m}$ dari permukaan tanah (Gambar 5d). Daun 24-30 cm x 2.5 $-4 \mathrm{~cm}$, gundul, warna tangkai daun hijau kekuningan, permukaan bawah dan atas daun tidak berbulu (gundul); pelepah daun berbulu, kuping pelepah daun membundar, tinggi $1 \mathrm{~mm}$ dengan bulu kejur pendek 1-2 mm (Gambar 5e).

Persebaran: Dapat ditemukan hampir di seluruh Indonesia, seperti di Pulau Jawa, Sumatra, dan sebagainya.

Lokasi ditemukan: Desa Mentayan, Kec. Bantan, Kab. Bengkalis (01 $31^{\circ} 59.2^{\prime \prime} \& 102^{\circ} 16^{\prime}$ 48.8") Indra Rijaya 02; Desa Wonosari Timur, Kec. Bengkalis, Kab. Bengkalis (01²9'32.0” \& $\left.102^{\circ} 07^{\prime} 16.2^{\prime \prime}\right)$ Indra Rijaya 10 dan Desa Pendekik, Kec. Bengkalis, Kab. Bengkalis (0130'34.4” \& $102^{\circ} 05^{\prime} 50.7$ ') Indra Rijaya 11.

Habitat: Tumbuh pada daerah yang sangat kering dan sangat lembab bahkan dapat tumbuh pada daerah yang tergenang air 2-3 bulan.

Pemanfaatan: Bahan kontruksi bangunan, pagar rumah dan kandang ayam. 

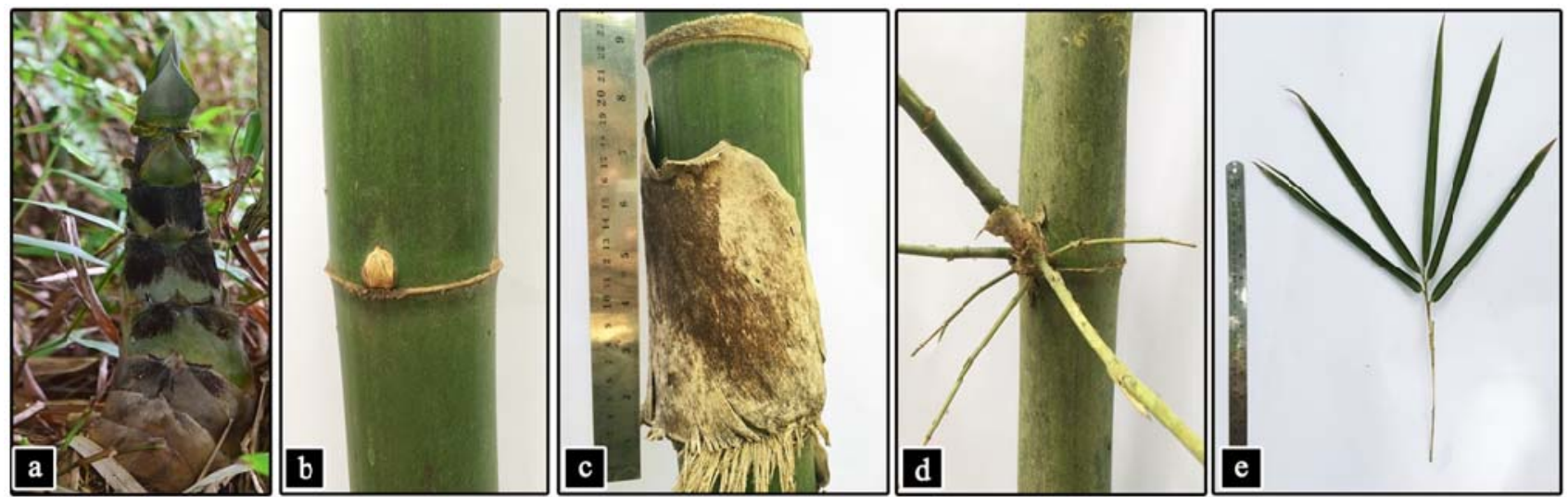

Gambar 5. B. vulgaris a. rebung; b. buku-buku; c. pelepah buluh; d. percabangan; e. daun.

\section{Bambusa vulgaris Schard. ex Wendl.var. striata} Sinonim:-

Nama umum/lokal: Bambu gading.

\section{Deskripsi:}

Rebung ramping menyegitiga, warna pelepah hijau dengan 3-4 garis kuning ditutupi miang cokelat tua; kuping membundar; daun pelepah rebung tegak (Gambar 6a). Buluh buluh tua kuning mengkilap dengan garis hijau, tegak, dengan tinggi 11$15 \mathrm{~m}$, diameter buluh 9-13 cm, ketebalan dinding 6-10 $\mathrm{mm}$, ruas panjangnya $20-45 \mathrm{~cm}$; buku-buku dengan akar udara hanya di bagian pangkalnya dan bagian keatas tidak terdapat akar udara (Gambar $6 b)$. Pelepah buluh mudah luruh, cokelat muda dengan permukaan abaksial tertutup bulu hitam hingga cokelat, dengan panjang $12-17 \mathrm{~cm}$, lebar $18-25 \mathrm{~cm}$; kuping pelepah buluh membulat dengan ujung melengkung keluar, tinggi $1-2.5 \mathrm{~cm}$ dengan bulu kejur 1-4 mm; ligula menggerigi, tinggi 2-4 mm dengan bulu kejur pendek; daun pelepah buluh tegak, menyegitiga dengan bagian pangkal melebar, panjang daun pelepah $5-6 \mathrm{~cm}$, lebar 6-7 cm (Gambar 6c). Percabangan setiap ruas terdiri atas 2-5 cabang dengan satu cabang lebih besar daripada cabang lainnya, tumbuh 1.5 $\mathrm{m}$ tingginya dari permukaan tanah (Gambar 6d). Daun 23-28 cm x 3-4 cm, gundul, warna tangkai daun hijau kekuningan; permukaan bawah tidak berbulu, permukaan atas pelepah daun berbulu; kuping pelepah buluh menggaris, tinggi $1 \mathrm{~mm}$ dengan bulu kejur yang pendek $1 \mathrm{~mm}$; ligula tidak tampak, gundul (Gambar 6e). Indonesia.

Persebaran: Hampir ditemukan di seluruh

Lokasi ditemukan: Desa Kelapa Pati Laut, Kec. Bengkalis, Kab. Bengkalis (“ $01^{\circ} 28$ ' 59,8” \& $102^{\circ}$ 05' 16.9”) Indra Rijaya 12 dan Desa Mentayan, Kec. Bantan, Kab.Bengkalis $\left(01^{\circ}\right.$ 32'28.8” \& 102¹6'24.9”). Indra Rijaya 07.

Habitat: Dapat tumbuh pada daerah lembab dan kering.

Pemanfaatan: Bahan kontruksi bangunan dan tanaman hias.
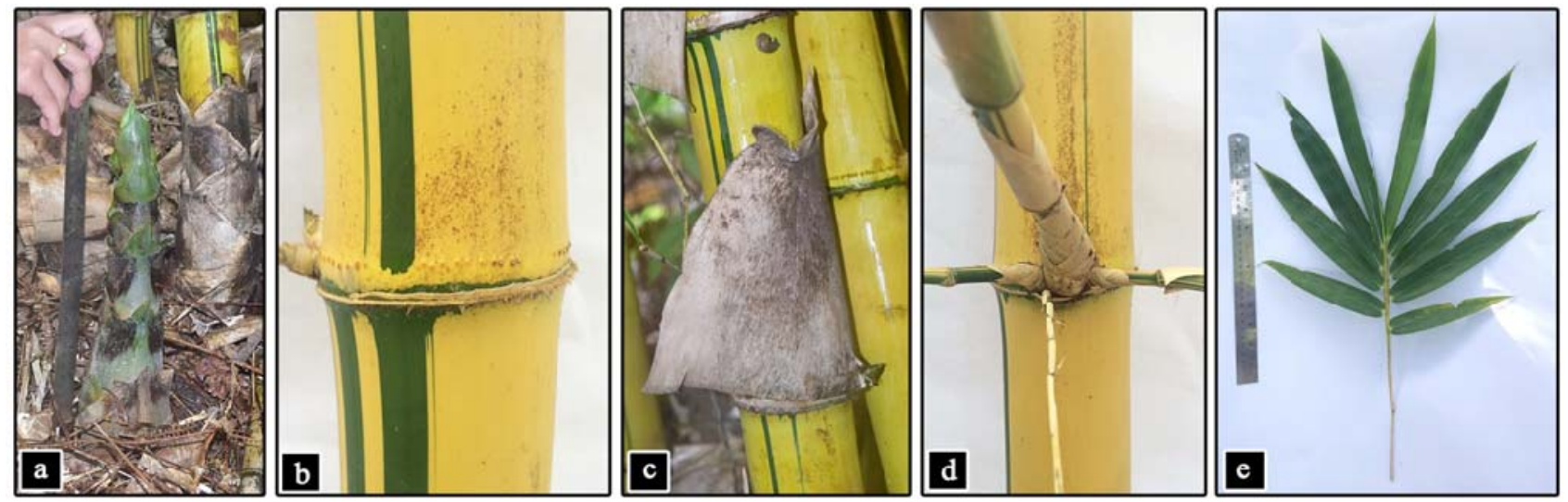

Gambar 6. B. vulgaris var striata a. rebung; b. buku-buku; c. pelepah buluh; d. percabangan; e. daun. 
Dendrocalamus asper (Schult.) Backer ex. Heyne Sinonim: Bambusa aspera Schult (1830)., Gigantochloa aspera (Schult.) Kurz (1876)., Dendroalamus flagellifer Munro (1866)., Dendrocalamus merrillianus (Elmer) Elmer (1915) (Widjaja 2001b; Dransfield \& Widjaja 1995).

Nama umum/lokal: Bambu betung/bambu petung.

\section{Deskripsi:}

Rebung bentuk mengerucut (bulat meruncing), ujung hitam keunguan; pelepah rebung kecokelatan tertutup bulu lebat berwarna cokelat tua; kuping pelepah rebung membundar; daun pelepah rebung tegak (Gambar 7a). Buluh tegak, berwarna hijau tua keputihan pada bagian atas buluh, bagian pangkal ditutupi bulu halus seperti beludru cokelat, buluh tua dengan totol putih, buku-buku dengan akar udara mulai dari pangkal hingga tengah keatas, tingginya berkisar 16-24 $\mathrm{m}$ dengan ujung melengkung, diameter $14-18 \mathrm{~cm}$, ketebalan dinding 8-11 cm, ruas panjangnya $40-50 \mathrm{~cm}$ (Gambar 7b). Pelepah buluh mudah luruh, permukaan adaksial licin (tidak berbulu), permukaan abaksial cokelat muda tertutup bulu hitam hingga kemerahan, panjang pelepah buluh $20-37 \mathrm{~cm}$ dengan lebar $25-30 \mathrm{~cm}$; kupingnya membulat terkeluk keluar dengan tinggi 15-19 mm, dengan bulu kejur panjangnya 3-6 $\mathrm{mm}$; ligula menggerigi, dengan panjang 4-7 $\mathrm{mm}$, bulu kejur pendek, panjangnya mencapai 2-3 $\mathrm{mm}$; daun pelepah buluh terkeluk balik, menyegitiga dengan dasar menyempit, panjang 15-18 cm, lebar 2-3 cm (Gambar 7c). Percabangan terdiri atas 5-11 cabang setiap ruas, satu cabang lebih besar dari pada cabang lainnya di bagian tengah buluh, jarak percabangan 1.1-3 m dari permukaan tanah (Gambar 7d). Daun 27-31 $\mathrm{cm} \times 2-4 \mathrm{~cm}$, permukaan atas tidak berbulu, permukaan bagian bawah agak berbulu, warna tangkai daun hijau kekuningan; permukaan pelepah daun tidak berbulu, kuping pelepah buluh kecil seperti bingkai, tinggi $1 \mathrm{~mm}$, panjang bulu kejur $1 \mathrm{~mm}$; ligula rata, tinggi $1 \mathrm{~mm}$ dengan panjang bulu kejur $1 \mathrm{~mm}$. Perbungaan tidak ditemukan (Gambar 7e).

Persebaran: Tumbuh tersebar di desa-desa Pulau Sumatra, Jawa.

Lokasi ditemukan: Desa Mentayan, Kec. Bantan, Kab. Bengkalis (“01 31' 59.6" \& $102^{\circ}$ 16' 49.2") Indra Rijaya 01.

Habitat: Tumbuh baik pada daerah yang lembab dan basah, tetapi juga dapat tumbuh di daerah kering.

Pemanfaatan: Bahan kontruksi bangunan, kerajinan tangan dan sayuran.
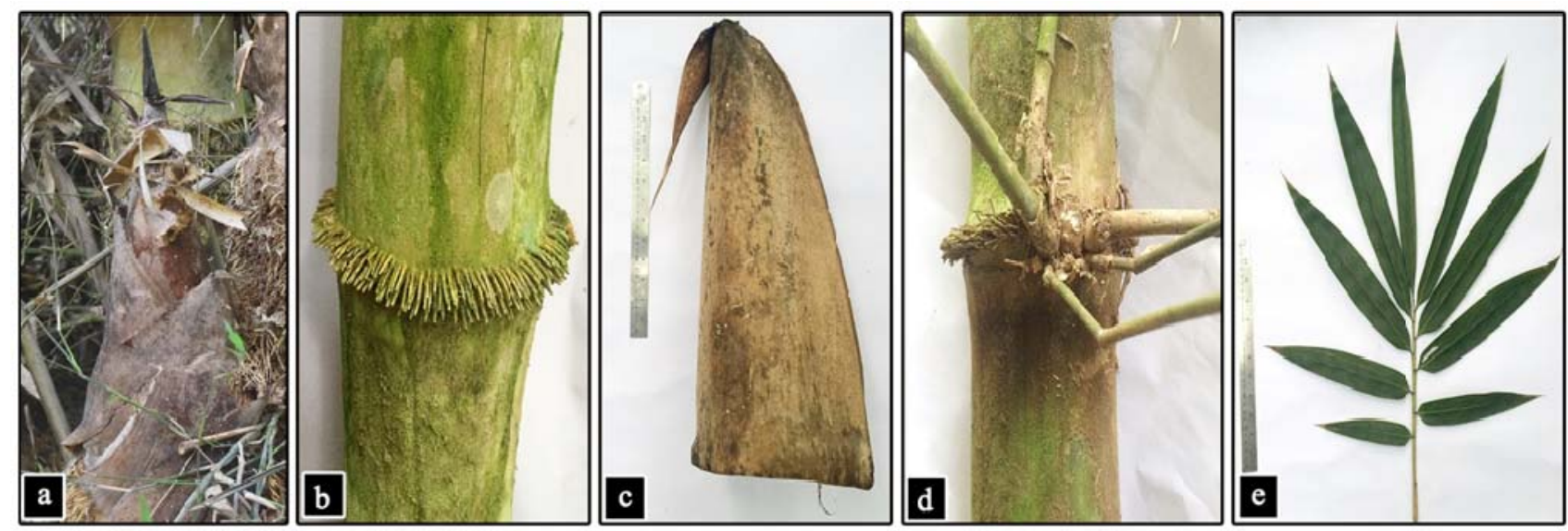

Gambar 7. D. asper a. rebung; b. buku-buku; c. pelepah buluh; d. percabangan; e. daun.

Gigantochloa hasskarliana (Kurz) Backer

Sinonim: Schizostachyum hasskarlianum Kurz (1876) (Widjaja 2001b; Dransfield \& Widjaja 1995).

Nama umum/lokal: Bambu apus/bambu tali Deskripsi:

Rebung bentuk mengerucut, warna pelepah rebung hijau kekuningan tertutup bulu hitam lebat; kuping pelepah rebung menggaris; daun pelepah rebung menyebar ketika muda (Gambar 8a). Buluh tegak, buku-buku polos, miang cokelat di bawah buku tersebar, buluh muda tertutup bulu cokelat tersebar, tetapi luruh ketika sudah tua, buluh tua berwarna hijau pucat atau hijau abu-abu, tingginya berkisar 16-22 m, diameter buluh 6-10 cm, ketebalan dinding $8-11 \mathrm{~mm}$; ruas panjangnya $46-60$ 
cm (Gambar 8b). Pelepah buluh tidak mudah luruh, cokelat muda tertutup bulu hitam di permukaan abaksial, panjang 20-25 cm, lebar 18-20 cm; kuping pelepah buluh seperti bingkai/menggaris dengan ujung ada bekas appendix yang patah, tinggi 1-3 mm, dengan bulu kejur panjangnya 3-6 $\mathrm{mm}$ mudah luruh; ligula menggerigi, tinggi 2-3 $\mathrm{mm}$ dengan bulu kejur $1 \mathrm{~mm}$; daun pelepah buluh menyadak hingga terkeluk balik, menyegitiga dengan pangkal menyempit, panjang $2-3 \mathrm{~cm}$, lebar 2 $-2.5 \mathrm{~cm}$ (Gambar 8c). Percabangan dengan satu cabang lateral lebih besar daripada cabang lainnya terdiri atas 5-11 cabang, jarak berkisar $1-1.5 \mathrm{~m}$ di permukaan tanah (Gambar 8d). Daun 30-42 cm x 7-9 cm, permukaan atas gundul, bagian bawah daun agak berbulu; warna tangkai daun hijau kekuningan; pelepah daun tidak berbulu, kuping pelepah daun kecil dan membundar, tinggi 1-2 mm, gundul; ligula rata, panjang 1-3 $\mathrm{mm}$, gundul (Gambar 8e).

Persebaran: Tumbuh di beberapa tempat di Jawa (G. Halimun, Taman Nasional Alas Purwo, Taman Nasional Meru Betiri) (Widjaja 2001a).

Lokasi ditemukan: Desa Mentayan, Kec. Bantan, Kab. Bengkalis (01 $31^{\circ} 58.8^{\prime \prime} \& 102^{\circ} 16^{\prime}$ 46.7"). Indra Rijaya 03.

Habitat: Tumbuh pada daerah lembab dan daerah perkebunan karet.

Pemanfaatan: kerajinan tangan.
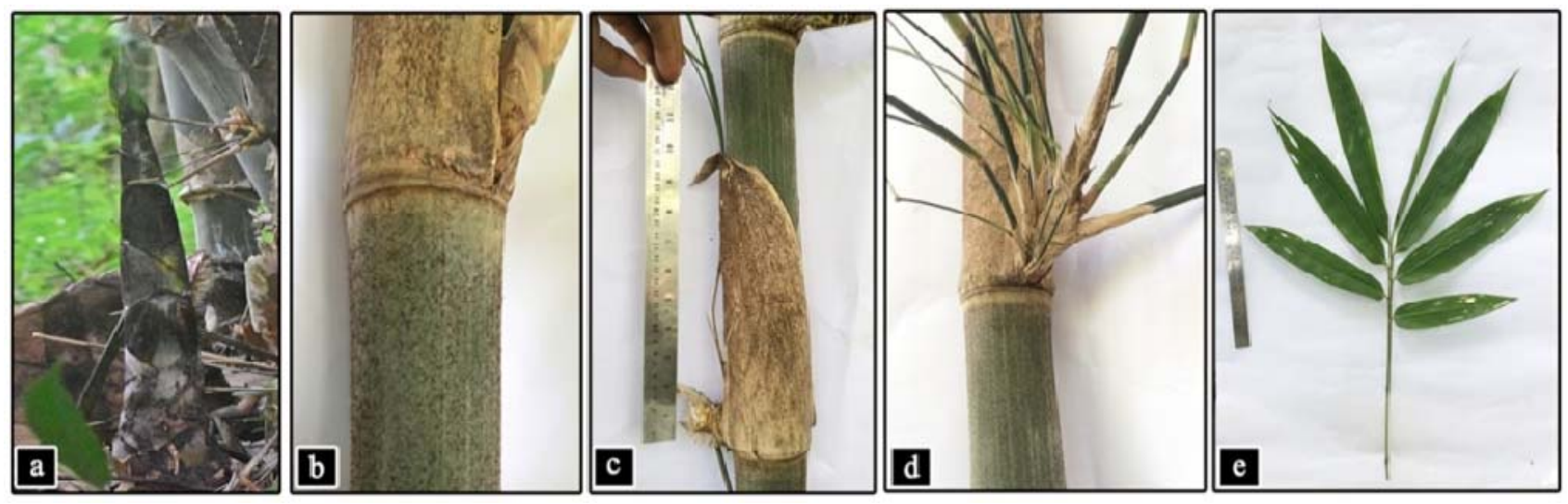

Gambar 8. G. hasskarliana a. rebung; b. buku-buku; c. pelepah buluh; d. percabangan; e. daun.

\section{Schizostachyum brachycladum Kurz}

Sinonim:-

Nama umum/lokal: Bambu lemang

Deskripsi:

Rebung bentuk ramping mengerucut; pelepah rebung kuning kecokelatan ditutupi miang cokelat kemerahan; kuping pelepah rebung membundar; daun pelepah rebung tegak (Gambar 9a). Buluh tegak, buku-buku dengan cincing/gelang putih yang melingkari buku, buluh tua hijau tua mengkilap, tinggi 11-15 m, diameter buluh 6-7 cm, ketebalan dinding $2-3 \mathrm{~mm}$, panjang ruas $30-40 \mathrm{~cm}$ (Gambar 9b). Pelepah buluh tidak mudah luruh, cokelat muda ditutupi bulu kemerahan hingga cokelat, panjang 10-13 cm, lebar 9-11 cm; kuping membulat kecil, tinggi $0.5-1 \mathrm{~cm}$, panjang bulu kejur 3-4 mm; ligula bergerigi, tinggi $1-2 \mathrm{~mm}$, bulu kejur $1 \mathrm{~mm}$; daun pelepah buluh tegak, pangkal menyegitiga melebar, panjang 6-7 cm, lebar 5-
$6 \mathrm{~cm}$ (Gambar 9c). Percabangan terdiri atas 4-9 dengan cabang sama besar dengan cabang yang lain setiap buku, tumbuh 30-80 cm tingginya dari atas permukaan tanah (Gambar 9d). Daun 30-37 x 3-5 cm, permukaan atas gundul, permukaan bawah agak berbulu halus, tangkai daun hijau kekuningan; pelepah daun berbulu, kuping bulat kecil, bulu kejur 2-3 mm; ligula rata, tinggi $1 \mathrm{~mm}$, bulu kejur 2-3 mm (Gambar 9e).

Persebaran: Di daerah Jawa varietas hijau hanya terdapat di beberapa tempat, sedangkan varietas kuning ditanam hampir di setiap kota (Widjaja 2001b).

Lokasi: Desa Kelapa Pati Laut, Kec. Bengkalis, Kab. bengkalis $\left(01^{\circ} 28^{\prime} 59,5^{\prime \prime} \& 102^{\circ}\right.$ 05' 16,4”). Indra Rijaya 13.

Habitat: Tumbuh pada daerah lembab hingga kering dan daerah sedikit terbuka.

Pemanfaatan: Pembungkus lemang. 

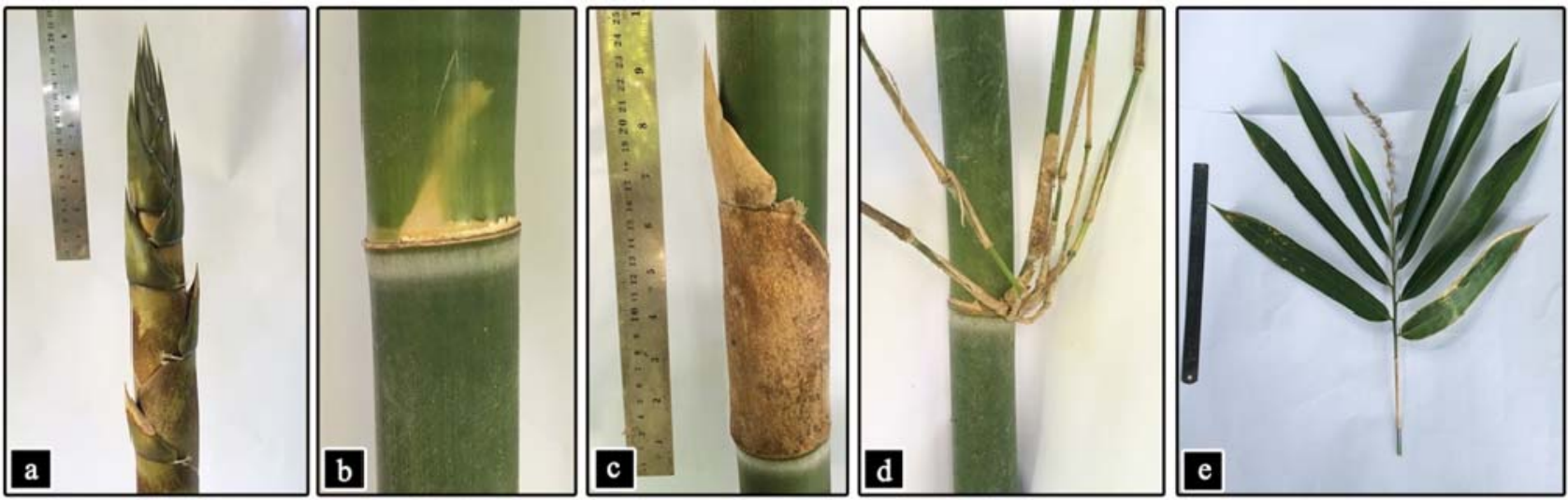

Gambar 9. S. brachycladum a. rebung; b. buku-buku; c. pelepah buluh; d. percabangan; e. daun.

\section{Schizostachyum latifolium Gamble}

Sinonim: Schizostachyum longispiculatum (Kurz ex Munro) Kurz sensu Holttum (1870), Ochlandra ridleyi (Gamble) Holttum (1947) (Dransfield \& Widjaja 1995).

Nama umum/lokal: Bambu suling

Deskripsi:

Rebung bentuk ramping, mengerucut, warna pelepah rebung hijau muda; pelepah buluh ditutupi miang cokelat kemerahan; kuping pelepah rebung menggaris; daun pelepah rebung terkeluk balik (Gambar 10a). Buluh tegak, buku-buku licin (polos), buluh muda tertutup bulu putih tersebar, buluh tua hijau tua tidak mengkilap, tinggi mencapai 7-15 m, diameter $1-3 \mathrm{~cm}$, ketebalan buluh 1-3 $\mathrm{mm}$, ruas $65-70 \mathrm{~cm}$ (Gambar 10b). Pelepah buluh tidak mudah luruh, cokelat muda tertutup bulu hitam pada permukaan abaksial, panjang $6-8 \mathrm{~cm}$, lebar 1-2 cm, ujung merompang; kuping pelepah buluh membulat, dengan bulu kejur panjangnya $0.1-0.3 \mathrm{~mm}$; ligula menggerigi, dengan beberapa bulu kejur halus yang mudah putus dan pendek; daun pelepah buluh terkeluk balik, mudah gugur, menyegitiga dengan pangkal mengecil, panjangnya lebih pendek dari pelepahnya, pangkalnya sempit, panjang 6-7 cm, lebar 1-3 cm (Gambar 10c). Percabangan terdiri 7-9 cabang dengan cabang sama besar dengan cabang yang lain, jarak percabangan $1.5 \mathrm{~m}$ dari permukaan tanah (Gambar 10d). Daun $18-28 \mathrm{~cm} \times 2.4-3.2 \mathrm{~cm}$, permukaan atas gundul, permukaan bawah berbulu, pelepah agak berbulu ketika muda, terutama di bagian ujung dan tepi; kuping pelepah daun membulat hingga melengkung keluar tetapi mudah patah, permukaan pelepah daun tertutupi bulu, panjang 1-2 $\mathrm{mm}$, dengan bulu kejur 2-5 mm pada kuping pelepah daun; ligula rata dengan tinggi mencapai $1 \mathrm{~mm}$, gundul (Gambar 10e).

\section{Persebaran:-}

Lokasi ditemukan: Desa Mentayan, Kec. Bengkalis, Kab. Bengkalis (01 $32^{\prime} 03.1^{\prime \prime} \& 102^{\circ}$ 16' 09.0"). Indra Rijaya 04.

Habitat: Ditemukan pada daerah perkebunan kelapa sawit dan sedikit lembab.

Pemanfaatan: Sebagai pembuatan alat musik, seperti suling dan angklung.
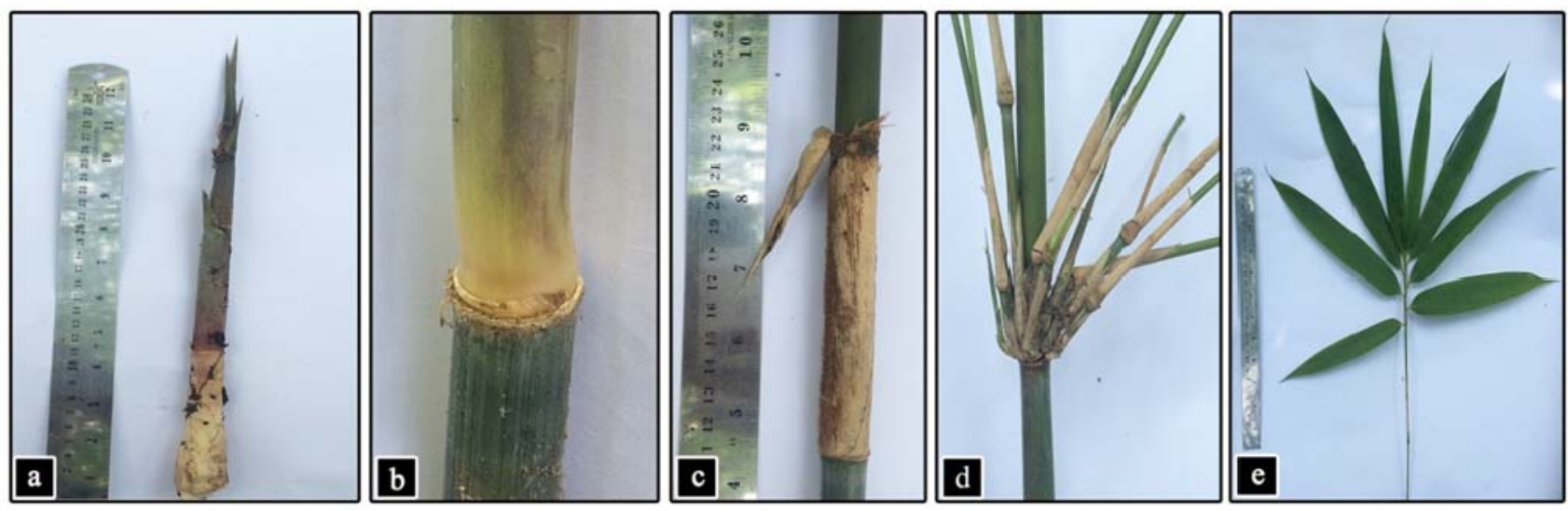

Gambar 10. S. latifolium a. rebung; b. buku-buku; c. pelepah buluh; d. percabangan; daun. 
Thyrsostachys siamensis Gamble

Sinonim: Thyrsostachys regia (Munro) Bennet (1988) (Dransfield \& Widjaja 1995).

Nama umum/lokal: Bambu pagar

Deskripsi:

Rebung bentuk ramping; pelepah rebung hijau keunguan ditutupi miang putih, kuping pelepah rebung tidak tampak, daun pelepah rebung tegak (Gambar 11a). Buluh tegak, buku-buku licin (polos), buluh muda hijau pucat, buluh tua hijau keabu-abuan dilapisi oleh lilin yang tersebar, tinggi berkisar 7-8 $\mathrm{m}$, diameter buluh 3-5 $\mathrm{cm}$, ketebalan 16-20 mm, ruas panjangnya $25-30 \mathrm{~cm}$ (Gambar 11b). Pelepah buluh tidak mudah luruh, cokelat muda tertutup bulu putih, panjang pelepah buluh 11-20 cm, lebar 3-5 cm; kuping pelepah buluh tidak tampak, gundul; ligula rata, tingginya $1 \mathrm{~mm}$, gundul; daun pelepah buluh tegak dan mudah gugur dengan pangkal melebar, panjang $1-3 \mathrm{~cm}$, le- bar 2-5 mm (Gambar 11c). Percabangan setiap ruas terdiri atas 3-6 cabang dengan satu cabang lebih besar daripada cabang lainnya, tumbuh 1.5-2 $m$ tingginya dari permukaan tanah (Gambar 11d). Daun memita/menggaris $10-14 \mathrm{~cm} \times 0.8-1 \mathrm{~cm}$, permukaan atas dan bawah gundul; pelepah daun tidak berbulu, kuping pelepah daun tidak tampak, gundul; ligula rata, tingginya kurang dari $1 \mathrm{~mm}$, gundul (Gambar 11e).

Persebaran: Tumbuh tersebar dan terutama di kota-kota besar, sedangkan di Jawa sudah ditanam hingga ke pelosok-pelosok desa.

Lokasi ditemukan: Desa Wonosari Timur, Kec. Bengkalis, Kab. Bengkalis $\left(01^{\circ}\right.$ 28 '50.1" \& $102^{\circ} 07^{\prime} 27,6^{\prime \prime}$ ). Indra Rijaya 14. Habitat: Tumbuh baik pada daerah lembab dan juga kering, dapat ditemukan di daerah perkarangan rumah warga.

Pemanfaatan: Tanaman hias.
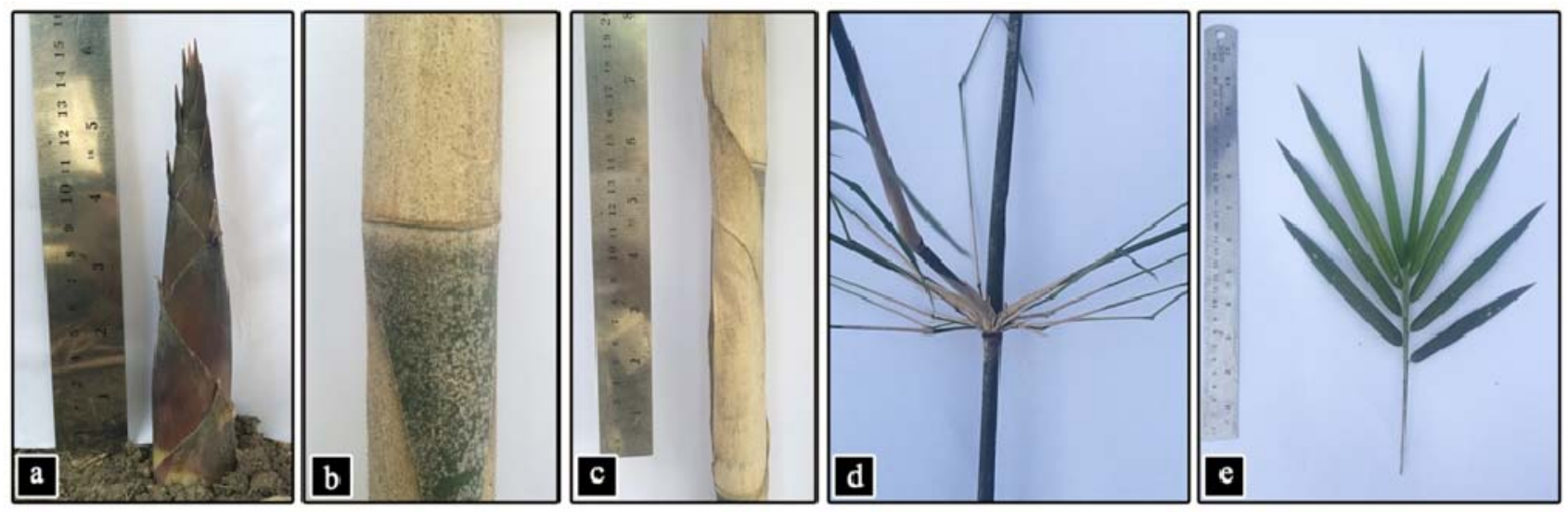

Gambar 11. T. siamensis a. rebung; b. buku-buku; c. pelepah buluh; d. percabangan; e. daun.

\section{KESIMPULAN}

Hasil inventarisasi dan identifikasi jenisjenis bambu di Pulau Bengkalis diperoleh empat marga asli dan satu marga introduksi yaitu Bambusa, Dendrocalamus, Gigantochloa, Schizostacyum dan Thyrsostachys. Terdapat sembilan jenis bambu yaitu B. glaucophylla, B. heterostachya, B. multiplex, B. vulgaris, D. asper, G. hasskarliana, S. brachycladum, S. latifoliumdan T. siamensis, serta satu varietas yakni $B$. vulgaris var. striata. Di Pulau Bengkalis bambu dimanfaatkan sebagai bahan konstruksi bangunan, alat rumah tangga, alat musik, tanaman pagar dan tanaman hias. Dengan demikian dapat dikatakan bahwa jenis-jenis tersebut merupakan jenis yang masih dapat tumbuh dengan baik di lahan gambut dan tanah asam.

\section{UCAPAN TERIMAKASIH}

Penulis mengucapkan terimakasih kepada Kepala Bidang Botani, Puslit Biologi, LIPI, Cibinong yang telah memberikan ijin magang di Herbarium Bogoriense sehingga dapat mengenal bambu di Provinsi Riau. Selain itu juga ucapan terima kasih ditujukan kepada Ibu Dr. Deby Arifiani dan Bapak I Putu Gede Parlida Damayanto M.Si ketika magang di Herbarium Bogoriense dan juga kepada semua pihak terkait, yang telah mendukung dan membantu baik secara moril maupun materil sehingga penelitian ini dapat terlaksana. 


\section{DAFTAR PUSTAKA}

Bamboo Phylogeny Group. 2012. An Updated Tribal and Subtribal Classification of the Bamboos (Poaceae: Bambusoideae). Bamboo Sciense and Culture: The Journal of the American Bamboo Society 24(1): 1-10.

Bean T. 2013. Collecting and Preserving Plant Specimens, A Manual. State of Queensland, Departement of Science. Queensland.

Dahlan Z. 1994. Penelitian Biologi, Budidaya dan Pemanfaatan Bambu di Universitas Sriwidjaja. Dalam: Widjaja EA, MA Rifai, B Subiyanto \& D Nandika (Penyunting). Strategi Penelitian Bambu Indonesia. Yayasan Bambu Lingkungan Lestari. Bogor.

Dransfield \& Widjaja EA. 1995. Plant Resources of South-East Asia no.7, Bamboos. Prosea. Bogor. 189 hlm.

Hartutiningsih \& Siregar M. 1996. Bambu Betung: dalam Lembar informasi Prosea. Prosea Indonesia. Indonesia.

Rugayah, Retnowati A, Windadri FI \& Hidayat A. 2004. Pengumpulan Data Taksonomi. Dalam: Rugayah, Widjaja EA \& Praptiwi (eds.). Pedoman Pengumpulan Data Keanekaragaman Flora. Bogor: Puslit-LIPI.pp. 5 42.

Situs Pemerintah Kabupaten Bengkalis. 2012. www.ppk-kp3k.kkp.go.id/direktori-pulau/ index.php/public_c/pulau_info/291. (Diakses pada minggu, 07 Mei 2017 di Pekanbaru).

Soekartawi. 1995. Analisis Usaha Tani. UI-Press. Jakarta.

Sukawi. 2010. Bambu Sebagai Alternatif Bahan Bangunan dan Konstruksi di Daerah Rawan Gempa. TERAS 10(1): 1-10.
Wahyunto \& B Heryanto. 2005. Sebaran Gambut dan Status Terkini di Sumatra. Pemanfaatan Lahan Gambut Secara Bijaksana Untuk Manfaat Berkelanjutan. Seri Prosiding 08 CCFPI. Bogor.

Wahyunto, S Ritung, Suparto \& H Subagjo. 2005. Sebaran Gambut dan Kandungan Karbon di Sumatera dan Kalimantan. Proyek Climate Change, Forest and Peatlands in Indonesia. Wetland Int'1-Indonesia Programme and Wildlife Habitat Canada. Bogor, Indonesia. 254 hal.

Widnyana K. 2012. Bambu dengan berbagai manfaatnya. Bumi Lestari, [S.l.] 8(1): 1-10. ISSN 2527-6158.

Widjaja EA. 1997. New Taxa in Indonesian Bamboos. Reindwartia 11(2): 57-152.

Widjaja EA. 2001a. Identikit Jenis-jenis Bambu di Jawa. Puslitbang Biologi-LIPI. Bogor.

Widjaja EA. 2001b. Identikit Jenis-jenis Bambu di Kepulauan Sunda Kecil. Puslitbang Biologi -LIPI. Bogor.

Widjaja EA \& Karsono. 2005. Keanekaragaman Bambu di Pulau Sumba. Biodiversitas.6 (2): 95-99.

Widjaja EA, Astuti IP, Arinasa IBK \& Sumantera IW. 2005. Identikit Bambu di Bali. Puslitbang Biologi - LIPI, Bogor.

Widjaja EA. 2014. Budidaya bambu untuk menunjang pemanfaatan dan konservasinya. Makalah dalam Lokakarya Bambu Flores di Borong tanggal 2-5 September 2014.

Wondafrash M. 2008. A Preliminary Guide to the Plant Collection, Identification And Herbarium Techniques. Addis Ababa. The national Herbarium AAU.

Wong KM. 2004. Bamboos The Amazing Grass. International Plant Genetic Resources Institute (IPGRI) and University Malaya. Kuala Lumpur. 